\author{
Rahhutami, R. • A.S. Handini · D. Astutik
}

\title{
Respons pertumbuhan pakcoy terhadap asam humat dan Trichoderma dalam media tanam pelepah kelapa sawit
}

Sari. Pemanfaatan limbah organik dari perkebunan sebagai media tanam pakcoy (Brassica chinensis L.) diharapkan dapat ditingkatkan dengan penggunaan pupuk organik serta pupuk hayati. Penelitian disusun menggunakan Rancangan Acak Kelompok (RAK) pola faktorial. Faktor pertama adalah dosis asam humat meliputi 1, 3, dan 5 g. Faktor kedua adalah dosis Trichoderma sp., meliputi 50, 100, dan $150 \mathrm{~mL}$. Data yang diperoleh kemudian dianalisis ragam pada taraf nyata 5\%. apabila terdapat pengaruh nyata, dilanjutkan dengan uji DMRT. Hasil penelitian menunjukkan bahwa aplikasi asam humat dan Trichoderma sp. memiliki pengaruh mandiri dan tidak terdapat interaksi. Dosis asam humat $3 \mathrm{~g}$ per tanaman menghasilkan jumlah daun, panjang daun, tinggi tanaman, tinggi tanaman, bobot basah, dan bobot kering tanaman lebih tinggi dibanding dosis 1 dan 5 g. Perlakuan Trichoderma sp. dosis $50 \mathrm{~mL}$ per tanaman memiliki pengaruh lebih baik terhadap jumlah daun, panjang daun, tinggi tanaman, dan bobot basah tanaman.

Kata kunci: Hortikultura · Jamur · Morfologi · Senyawa organik

\section{Response of pakcoy growth to humic acid and Trichoderma in the use of oil palm frond as growing media}

\begin{abstract}
The utilization of organic farm estate as pakcoy (Brassica chinensis L.) growing media may improved by using biofertilizer and organic fertilizer. The research used factorial randomized block design. First factor was humic acid dosage, which included 1, 3, and $5 \mathrm{~g}$ of humic acid. Second factor was Trichoderma sp. dosage, which included 50, 100, and $150 \mathrm{~mL}$ of Trichoderma sp. Data were analyzed using ANOVA at 5\% level, then continued by DMRT test. The results showed that the application of humic acid and Trichoderma sp. had single effects and there was no interaction. The dosage of humic acid $3 \mathrm{~g}$ per plant had higher number of leaves, leaf length, plant height, wet weight, and dry weight than other dosages. The treatment of Trichoderma sp. at dosage of $50 \mathrm{~mL}$ per plant had a better effect on the number of leaves, leaf length, plant height, and plant wet weight.
\end{abstract}

Keywords: Fungi $\cdot$ Horticulture $\cdot$ Morphology $\cdot$ Organic compounds

Diterima : 10 Maret 2021, Disetujui : 29 Juli 2021, Dipublikasikan : 1 Agustus 2021

DOI: https:// doi.org/10.24198/kultivasi.v20i2.32601

\footnotetext{
Rahhutami, R. ${ }^{1}$ A.S. Handini' ${ }^{2}$ D. Astutik ${ }^{3}$

${ }^{1}$ Budidaya Perkebunan Kelapa Sawit, Politeknik Kelapa Sawit Citra Widya Edukasi

2 Teknologi Produksi Tanaman Perkebunan, Politeknik Kelapa Sawit Citra Widya Edukasi

${ }^{3}$ Balai Penelitian Tanaman Industri dan Penyegar

Korespondensi: rahhutamiratih@gmail.com
} 


\section{Pendahuluan}

Pakcoy (Brassica chinensis L.) merupakan salah satu jenis sayuran yang banyak dikonsumsi oleh masyarakat, sehingga kebutuhan sayuran ini semakin meningkat seiring bertambahnya jumlah penduduk. Data impor sayuran di Indonesia pada tahun 2019 sebanyak 770,378 ton. Pertumbuhan produksi sayuran jenis sawi dari tahun 2015 sampai tahun 2019 meningkat 2,63\% dari 600 ton menjadi 652 ton. (Badan Pusat statistik dan Direktorat Jenderal Hortikultura 2020). Produksi sayuran jenis sawi harus tetap ditingkatkan agar Indonesia mampu memenuhi kebutuhan sayuran dalam negeri tanpa harus mengimpor dari negara lain, sehingga perlu ada inovasi teknik budidaya untuk meningkatkan produksi pakcoy. Salah satu cara yang dapat dilakukan adalah dengan meningkatkan kesuburan tanah yang digunakan untuk budidaya pakcoy.

Upaya yang dilakukan untuk meningkatkan kesuburan tanah sudah banyak dilaporkan. Yuniarti et al. (2019) menunjukkan bahwa aplikasi macam pupuk organik dan pupuk $\mathrm{N}, \mathrm{P}, \mathrm{K}$ memberikan pengaruh terhadap C-organik, $\mathrm{C} / \mathrm{N}$, serapan $\mathrm{N}$, serta hasil padi hitam pada tanah inceptisols. Priambodo et al. (2019) menyatakan bahwa perlakuan pupuk hayati pada dosis $20 \mathrm{~mL}$ memberikan pengaruh nyata terhadap perbaikan sifat kimia tanah, pertumbuhan, dan peningkatan hasil tanaman bayam. Karyaningsih (2012) lebih lanjut melaporkan bahwa pemanfaatan limbah pertanian (jerami padi dan kotoran ternak) selama satu tahun di Desa Tegalsari mampu menyediakan pupuk organik 1.427 ton yang dapat digunakan untuk perbaikan kualitas lahan seluas 238 ha.

Pelepah kelapa sawit merupakan salah satu limbah perkebunan kelapa sawit yang berpotensi dijadikan sumber bahan organik bagi tanaman. Syahfitri (2008) menunjukkan bahwa pelepah kelapa sawit mengandung unsur N 2,6 - 2,9 \%; P 0,16 - 0,19 \%; K 1,1 - 1,3 \%; Ca 0,5 - 0,7 $\%$; Mg 0,3 - 0,45\%; S 0,25 - 0,40\%; dan Cl 0,5 $0,7 \%$. Tanaman kelapa sawit mengeluarkan 18 30 pelepah setiap tahunnya. Rerata pelepah yang dipotong setiap panen kelapa sawit adalah $1-3$ pelepah jadi setiap bulannya ada $2-4$ pelepah yang harus dipotong dengan bobot 5,40 kg per pelepah (Darmosarkoro, 2012). Dalam hasil penelitiannya, Zainudin dan
Kesumaningwati (2020) menunjukkan bahwa populasi jamur pada lahan sub optimal mengalami peningkatan dengan penambahan kompos pelepah kelapa sawit dengan bioaktivator POME. Pada penelitian ini, limbah pelepah kelapa sawit yang telah dikomposkan digunakan sebagai media tanam untuk meningkatkan ketersediaan unsur hara. Hasil dekomposisi tersebut menghasilkan senyawa organik yang dapat menyuburkan tanah. Senyawa tersebut disebut dengan asam humat.

Asam humat atau humus merupakan senyawa yang berasal dari sisa-sisa hewan dan tumbuhan yang telah mengalami perombakan oleh organisme yang ada di dalam lapisan tanah. Asam humat ini berwarna gelap (coklat kehitaman) dan bertekstur gembur (Pettit, 2018). Pemberian asam humat dapat menurunkan evapotranspirasi, meningkatkan water holding capacity, menurunkan erosi tanah, memperbaiki struktur tanah, dan meningkatkan KTK tanah (Khaled dan Fawy, 2011). Pemberian asam humat pada media tanam zeolit memberikan pengaruh yang sangat nyata terhadap jumlah daun, berat basah dan berat kering akar, batang, daun serta kandungan vitamin $C$ sawi hijau. Asam humat dengan konsentrasi $4 \mathrm{~g}$ $\mathrm{kg}^{-1}$ merupakan konsentrasi yang paling efisien dalam meningkatkan pertumbuhan dan kandungan vitamin C sawi hijau (Fauziah, et al. 2019). Sukri et al. (2019) menunjukkan bahwa kombinasi pupuk kandang dan asam humat dapat meningkatkan unsur hara tersedia di dalam tanah sebesar 191,84\% untuk unsur hara nitrogen dan 291,20\% untuk unsur hara fosfat. Aplikasi asam humat dosis $50 \mathrm{~g} /$ polybag memiliki tinggi bibit, jumlah daun, dan rasio tajuk akar bibit kelapa sawit lebih tinggi dibandingkan dosis $25 \mathrm{~g}$ /polybag (Sembiring et al., 2015). Penambahan asam humat $0,75 \mathrm{~g} /$ bibit tembakau meningkatkan parameter tinggi bibit, diameter batang, dan luas daun (Wahyuni, 2018). Asam humat dengan dosis 40 $\mathrm{mg} /$ tanaman menghasilkan berat kering tertinggi dibandingkan dengan dosis 20 $\mathrm{mg} /$ tanaman (Bangun, 2016). Asam humat diaplikasikan sebagai pelapis urea dengan dosis $800 \mathrm{~mL}$ asam humat $/ 200 \mathrm{~kg}$ urea/ha memberikan pengaruh yang baik terhadap jumlah daun, luas daun, dan bobot segar tajuk tanaman pakcoy (Radite dan Simanjuntak, 2020). Dari penelitian tersebut dapat disimpulkan bahwa dosis asam humat yang digunakan adalah 1, 3, dan 5 g. Hal ini dengan 
pertimbangan jenis tanah yang digunakan adalah sub soil yang tidak subur.

Agen hayati yang dapat digunakan untuk mempercepat proses dekomposisi bahan organik adalah Trichoderma sp. Sakiah et al (2019) melaporkan bahwa pemberian kotoran sapi dan Trichoderma harzianum pada pengomposan pelepah kelapa sawit menghasilkan kadar Corganik, $\mathrm{N}, \mathrm{P}, \mathrm{K}$, dan rasio $\mathrm{C} / \mathrm{N}$ kompos yang telah memenuhi standar mutu kompos berdasarkan SNI 19-7030-2004. Spesies Trichoderma sp. disamping sebagai organisme pengurai, dapat berfungsi juga sebagai agen hayati, stimulator pertumbuhan tanaman, dan sebagai biofungisida. Selain itu, Trichoderma sp. juga memberikan pengaruh positif terhadap perakaran tanaman, pertumbuhan tanaman, dan hasil produksi tanaman cabai (Herlina dan Pramesti, 2009). Perlakuan Trichoderma isolat bawang efektif dalam mengendalikan penyakit akar gada dan meningkatkan hasil tanaman caisim, dengan menekan intensitas penyakit di atas tanah sebesar 50,00 \%, menekan intensitas di dalam tanah sebesar $34,48 \%$, menurunkan volume akar gada sebesar $72,73 \%$, menunda masa inkubasi sebesar 26,65 \%, meningkatkan jumlah daun sebesar 18,12\%, dan bobot basah sebesar 30,75 \% (Yudha et al., 2016).

Berdasarkan uraian yang telah dijelaskan tentang manfaat dari asam humat dan Trichoderma sp. serta potensi limbah pelepah kelapa sawit dalam meningkatkan kesuburan tanah, maka penelitian ini perlu dilakukan untuk meningkatkan produksi tanaman pakcoy. Penelitian ini bertujuan untuk mengetahui pengaruh asam humat dan Trichoderma sp. serta interaksi antara keduanya dan mendapatkan dosis terbaik dari asam humat dan Trichoderma sp. serta kombinasi keduanya terhadap parameter pertumbuhan tanaman pakcoy, yaitu jumlah daun, panjang daun, tinggi tanaman, bobot basah, bobot kering, C organik, dan kadar $\mathrm{N}$ total tanaman yang ditanam pada campuran tanah dan limbah pelepah kelapa sawit.

\section{Bahan dan Metode}

Percobaan ini dilakukan di Kebun Percobaan Politeknik Kelapa Sawit Citra Widya Edukasi pada September sampai Oktober 2020 menggunakan polybag. Bahan yang digunakan adalah benih pakcoy, limbah pelepah kelapa sawit, tanah sub soil tanah latosol, dekomposer
EM4, pupuk daun Growmore, pestisida nabati komersil, polybag, asam humat komersil, dan Trichoderma sp komersil. Alat yang digunakan adalah timbangan digital, penggaris, dan oven. Penelitian ini menggunakan Rancangan Acak Kelompok (RAK) pola faktorial dengan faktor pertama adalah dosis asam humat dan faktor kedua adalah dosis Trichoderma. Faktor pertama terdiri dari 1, 3, dan $5 \mathrm{~g}$ asam humat. Faktor kedua terdiri dari 50, 100, dan $150 \mathrm{~mL}$ Trichoderma sp. Setiap perlakuan diulang tiga kali sehingga terdapat 27 satuan percobaan, dan setiap satuan percobaan terdapat 3 tanaman sehingga total tanaman percobaan sebanyak 81 tanaman. Teknik percobaan dimulai dengan pengomposan pelepah kelapa sawit. Pengomposan dilakukan selama 1 bulan kemudian dilakukan penyemaian benih pakcoy selama 12 hari setelah itu tanaman dipindahkan ke polybag berukuran $15 \times 15 \mathrm{~cm}$ yang telah berisi media tanam campuran tanah sub soil latosol dan kompos pelepah kelapa sawit dengan perbandingan 2:1. Bibit pakcoy yang siap pindah tanam ke polybag memiliki ciri-ciri sudah tumbuh daun berjumlah 2 helai. Pemberian asam humat dilakukan pada saat pindah tanam ketika tanaman berusia 12 hari setelah tanam (HST) dengan cara mencampurkan asam humat pada media tanam sesuai dosis yang telah ditentukan. Sedangkan pemberian Trichoderma sp. dilakukan sebanyak 3 kali dimulai pada saat pindah tanam (0 MST), 1 MST, dan 2 MST sesuai dosis yang telah ditentukan. Dilakukan juga kegiatan perawatan tanaman dengan pemberian pupuk daun diawal penanaman sebanyak $20 \mathrm{~g}$ yang dilarutkan dengan $10 \mathrm{~L}$ air, dan pada umur 2 MST diberikan pestisida nabati sebanyak $100 \mathrm{~mL}$ yang dilarutkan dengan $20 \mathrm{~L}$ air. Pupuk daun dan pestisida nabati kemudian disemprotkan pada bagian daunnya. Pestisida nabati yang digunakan berasal dari tumbuhan dan bahan organik lain untuk mengendalikan ulat daun. Parameter pengamatan meliputi jumlah daun, panjang daun, dan tinggi tanaman yang diamati setiap minggu, mulai tanaman berumur 1 MST sampai 3 MST. Sementara parameter bobot basah dan bobot kering diamati di akhir penelitian. Analisis kadar hara tanah dan tanaman dilakukan di Laboratorium Agronomi dan Hortikultura IPB. Kadar hara tanah dan tanaman ini diambil di akhir penelitian ketika tanaman berusia 3 MST. Sampel tanah dan tanaman diambil dengan cara semua sampel (1, 
2, dan 3) dalam satu perlakuan yang sama dijadikan komposit sehingga total sampel yang dikirim ke laboratorium sebanyak 27 sampel tanah dan 27 sampel tanaman. Data yang diperoleh kemudian dianalisis ragam pada taraf nyata 5\%. Apabila terdapat pengaruh nyata, maka uji dilanjutkan dengan Duncan Multiple Range Test (DMRT) pada taraf nyata 5\%. Olah data menggunakan software STAR.

\section{Hasil dan Pembahasan}

Pemberian berbagai dosis asam humat berpengaruh nyata pada jumlah daun, panjang daun, dan tinggi tanaman, serta bobot basah dan kering tanaman, sedangkan pemberian berbagai dosis Trichoderma sp. berpengaruh nyata pada jumlah daun, panjang daun, tinggi tanaman, dan bobot basah tanaman. Tidak terdapat interaksi antara asam humat dan Trichoderma sp. yang diberikan (Tabel 1 sampai 4). Pada Tabel 1 terlihat bahwa dosis asam humat $3 \mathrm{~g}$ memiliki jumlah daun lebih banyak dibanding dosis $5 \mathrm{~g}$, namun tidak berbeda nyata dengan dosis $1 \mathrm{~g}$. Pada parameter panjang daun dan tinggi tanaman aplikasi asam humat tidak memiliki pengaruh yang signifikan (Tabel 2 dan Tabel 3). Parameter bobot basah dan kering tanaman yang ditunjukkan oleh tabel 4 terlihat bahwa untuk bobot basah, dosis $3 \mathrm{~g}$ memiliki bobot basah yang lebih tinggi dibandingkan pada perlakuan dosis $1 \mathrm{~g}$ dan $5 \mathrm{~g}$. Dosis $1 \mathrm{~g}$ asam humat tidak berbeda nyata dengan dosis $5 \mathrm{~g}$. Parameter bobot kering tanaman pakcoy dengan dosis $1 \mathrm{~g}$ dan $3 \mathrm{~g}$ asam humat memiliki bobot lebih tinggi dibanding dosis $5 \mathrm{~g}$. Dosis $1 \mathrm{~g}$ tidak berbeda nyata dengan dosis $3 \mathrm{~g}$, namun berbeda nyata dengan dosis 5 g. Saragih (2015) melaporkan bahwa terdapat pengaruh asam humat dan pupuk NPK terhadap $\mathrm{pH} \mathrm{H}_{2} \mathrm{O}$, Serapan N, dan bobot segar pakcoy, tetapi tidak berpengaruh pada N-total tanah, serta memberikan pengaruh lebih baik pada hasil pakcoy (Brassica chinensis L.) yaitu 100,60 $\mathrm{g} /$ tanaman. Victolika et al. (2014) menyatakan bahwa asam humat dapat meningkatkan jumlah daun, indeks kehijauan daun, dan bobot buah per tanaman pada tanaman tomat. Begitupun dengan hasil penelitian Suwardi dan Wijaya (2013) yang menunjukkan asam humat dengan karier zeolit dapat meningkatkan produksi padi sekitar 15\% dan jagung 7\%. Malcolm dan
Vaughan (1979) berpendapat asam humat dapat meningkatkan aktivitas fosfatase dalam tanah yang menghidrolisis ester fosfat menjadi fosfor anorganik yang tersedia bagi tanaman.

Tabel 1. Pengaruh pemberian asam humat dan Trichoderma sp terhadap jumlah daun tanaman pakcoy pada media tanam limbah pelepah kelapa sawit

\begin{tabular}{cccc}
\hline \multirow{2}{*}{ Perlakuan } & \multicolumn{3}{c}{ Jumlah Daun (Helai) } \\
& 1 MST & 2 MST & 3 MST \\
\hline Asam Humat & & & \\
$1 \mathrm{~g}$ & $3,85 \mathrm{a}$ & $5,52 \mathrm{a}$ & $8,81 \mathrm{ab}$ \\
$3 \mathrm{~g}$ & $3,70 \mathrm{a}$ & $5,89 \mathrm{a}$ & $9,37 \mathrm{a}$ \\
$5 \mathrm{~g}$ & $3,33 \mathrm{~b}$ & $4,81 \mathrm{~b}$ & $7,92 \mathrm{~b}$ \\
\hline Trichoderma sp. & & & \\
$50 \mathrm{~mL}$ & $3,70 \mathrm{a}$ & $5,70 \mathrm{a}$ & $9,54 \mathrm{a}$ \\
$100 \mathrm{~mL}$ & $3,55 \mathrm{a}$ & $5,44 \mathrm{a}$ & $8,30 \mathrm{~b}$ \\
$150 \mathrm{~mL}$ & $3,63 \mathrm{a}$ & $5,07 \mathrm{a}$ & $8,33 \mathrm{~b}$ \\
\hline KK $(\%)$ & 12,99 & 17,46 & 18,75 \\
\hline
\end{tabular}

Keterangan: Angka yang diikuti huruf yang sama pada kolom yang sama menunjukkan hasil yang tidak berbeda nyata berdasarkan DMRT pada $a=$ $5 \%, \mathrm{KK}=$ koefisien korelasi.

Tabel 2. Pengaruh pemberian asam humat dan Trichoderma sp. terhadap panjang daun tanaman pakcoy pada media tanam limbah pelepah kelapa sawit

\begin{tabular}{cccc}
\hline \multirow{2}{*}{ Perlakuan } & \multicolumn{3}{c}{ Panjang Daun (cm) } \\
& 1 MST & 2 MST & 3 MST \\
\hline Asam Humat & & & \\
$1 \mathrm{~g}$ & $4,70 \mathrm{a}$ & $8,75 \mathrm{a}$ & $10,16 \mathrm{a}$ \\
$3 \mathrm{~g}$ & $5,15 \mathrm{a}$ & $9,33 \mathrm{a}$ & $11,05 \mathrm{a}$ \\
$5 \mathrm{~g}$ & $3,17 \mathrm{~b}$ & $7,56 \mathrm{~b}$ & $10,15 \mathrm{a}$ \\
\hline Trichoderma sp. & & & \\
$50 \mathrm{~mL}$ & $4,50 \mathrm{a}$ & $9,33 \mathrm{a}$ & $10,81 \mathrm{a}$ \\
$100 \mathrm{~mL}$ & $4,20 \mathrm{a}$ & $8,45 \mathrm{ab}$ & $10,42 \mathrm{a}$ \\
$150 \mathrm{~mL}$ & $4,32 \mathrm{a}$ & $7,86 \mathrm{~b}$ & $10,15 \mathrm{a}$ \\
\hline KK $(\%)$ & 21,30 & 21,09 & 16,57 \\
\hline
\end{tabular}

Keterangan: Angka yang diikuti huruf yang sama pada kolom yang sama menunjukkan hasil yang tidak berbeda nyata berdasarkan DMRT pada $a=5 \%, \mathrm{KK}=$ koefisien korelasi.

Pemberian Trichoderma sp. memiliki pengaruh terhadap parameter jumlah daun 3 MST (tabel 1), panjang daun 2 MST (tabel 2), tinggi tanaman 2 MST (tabel 3), dan bobot basah tanaman (tabel 4). Tanaman pakcoy pada umur 2 MST dengan perlakuan Trichoderma sp. dosis 50 $\mathrm{mL}$ memiliki panjang daun dan tinggi tanaman lebih besar dibandingkan dengan dosis $100 \mathrm{~mL}$ dan $150 \mathrm{~mL}$. Pakcoy umur 3 MST dosis $5 \mathrm{~mL}$ 
memiliki jumlah daun yang lebih banyak dibandingkan perlakuan dosis $100 \mathrm{~mL}$ dan 150 $\mathrm{mL}$. Pada Tabel 4, pemberian Trichoderma sp. secara tunggal hanya berpengaruh pada bobot basah tanaman. Dosis $50 \mathrm{~mL}$ Trichoderma sp. memiliki bobot basah lebih tinggi dibandingkan dosis $100 \mathrm{~mL}$ dan $150 \mathrm{~mL}$. Dosis terbaik terlihat pada dosis $50 \mathrm{~mL}$ Trichoderma sp. dilihat dari ratarata hasil parameter tersebut. Hal ini diduga karena dosis $50 \mathrm{~mL}$ dapat dimanfaatkan secara maksimal, sesuai dengan perbandingan media tanam, dan sesuai ukuran polybag. Adanya penambahan dosis Trichoderma sp. sampai $150 \mathrm{~mL}$ memiliki pengaruh lebih rendah karena dosis terlalu tinggi sehingga persaingan antar Trichoderma sp. lebih ketat dan tidak memberikan pengaruh terhadap pakcoy. Hasil penelitian Rizal et al. (2019) menunjukkan bahwa pemberian Trichoderma sp. berpengaruh sangat nyata terhadap tinggi dan jumlah daun tanaman tomat. Lebih lanjut, Siregar et al. (2018) menunjukkan bahwa perlakuan Trichoderma sp. dengan dosis 20 $\mathrm{g} /$ tanaman merupakan perlakuan terbaik yang menghasilkan tinggi tanaman, jumlah cabang produktif, jumlah polong per tanaman, hasil per tanaman, dan produksi per plot kacang panjang yang lebih besar. Trichoderma sp. adalah salah satu mikroorganisme yang bermanfaat dan bersifat saling menguntungkan dengan akar-akar tanaman. Cendawan Trichoderma sp. banyak terdapat di alam dan tanah pertanian, dan umumnya berkoloni dengan akar dari banyak spesies tanaman. Cendawan Trichoderma sp. membantu tanaman inang menyerap unsur hara (Poulton et al., 2011).

Tabel 3. Pengaruh pemberian asam humat dan Trichoderma sp. terhadap tinggi tanaman pakcoy pada media tanam limbah pelepah kelapa sawit

\begin{tabular}{cccc}
\hline \multirow{2}{*}{ Perlakuan } & \multicolumn{3}{c}{ Tinggi Tanaman $(\mathrm{cm})$} \\
& 1 MST & 2 MST & 3 MST \\
\hline Asam Humat & & & \\
$1 \mathrm{~g}$ & $5,77 \mathrm{a}$ & $10,25 \mathrm{a}$ & $11,57 \mathrm{a}$ \\
$3 \mathrm{~g}$ & $6,08 \mathrm{a}$ & $10,86 \mathrm{a}$ & $12,46 \mathrm{a}$ \\
$5 \mathrm{~g}$ & $4,22 \mathrm{~b}$ & $8,82 \mathrm{~b}$ & $11,64 \mathrm{a}$ \\
\hline Trichoderma sp. & & & \\
$50 \mathrm{~mL}$ & $5,63 \mathrm{a}$ & $10,85 \mathrm{a}$ & $12,40 \mathrm{a}$ \\
$100 \mathrm{~mL}$ & $5,28 \mathrm{a}$ & $9,94 \mathrm{ab}$ & $11,83 \mathrm{a}$ \\
$150 \mathrm{~mL}$ & $5,15 \mathrm{a}$ & $9,13 \mathrm{~b}$ & $11,47 \mathrm{a}$ \\
\hline KK $(\%)$ & 18,29 & 18,94 & 15,81 \\
\hline
\end{tabular}

Keterangan: Angka yang diikuti huruf yang sama pada kolom yang sama menunjukkan hasil yang tidak berbeda nyata berdasarkan DMRT pada $\mathrm{a}=$ $5 \%, \mathrm{KK}=$ koefisien korelasi.
Tabel 4. Pengaruh pemberian asam humat dan Trichoderma sp. terhadap bobot basah dan kering tanaman pakcoy pada media tanam limbah pelepah kelapa sawit

\begin{tabular}{rcc}
\hline Perlakuan & $\begin{array}{c}\text { Bobot Basah } \\
(\mathrm{g})\end{array}$ & $\begin{array}{c}\text { Bobot Kering } \\
(\mathrm{g})\end{array}$ \\
\hline Asam Humat & & \\
$1 \mathrm{~g}$ & $6,82 \mathrm{~b}$ & $0,50 \mathrm{a}$ \\
$3 \mathrm{~g}$ & $8,91 \mathrm{a}$ & $0,56 \mathrm{a}$ \\
$5 \mathrm{~g}$ & $5,53 \mathrm{~b}$ & $0,34 \mathrm{~b}$ \\
\hline Trichoderma sp. & & \\
$50 \mathrm{~mL}$ & $8,70 \mathrm{a}$ & $0,54 \mathrm{a}$ \\
$100 \mathrm{~mL}$ & $6,29 \mathrm{~b}$ & $0,42 \mathrm{a}$ \\
$150 \mathrm{~mL}$ & $6,40 \mathrm{~b}$ & $0,45 \mathrm{a}$ \\
\hline KK $(\%)$ & 33,86 & 45,37
\end{tabular}

Keterangan : Angka yang diikuti huruf yang sama pada kolom yang sama menunjukkan hasil yang tidak berbeda nyata berdasarkan DMRT pada $a=$ $5 \%, \mathrm{KK}=$ koefisien korelasi.

Tabel 5. Hasil analisis hara media tanam dan tanaman pakcoy pada pemberian berbagai dosis asam humat dan Trichoderma sp.

\begin{tabular}{lcccc}
\hline Perlakuan & \multicolumn{3}{c}{ Data Pengamatan } \\
\hline \multicolumn{5}{c}{ Asam humat 1 g } \\
\cline { 2 - 5 } & $\begin{array}{c}\text { C- } \\
\text { Org } \\
(\%)\end{array}$ & $\begin{array}{c}\text { Total } \\
(\%)\end{array}$ & $\begin{array}{c}\text { N -Total } \\
(\%)\end{array}$ \\
\hline \multicolumn{5}{c}{ Asam humat 3 g } \\
Trichoderma $50 \mathrm{~mL}$ & 5,31 & 1,04 & 0,10 & 4,78 \\
Trichoderma $100 \mathrm{~mL}$ & 5,46 & 2,07 & 0,14 & 4,59 \\
Trichoderma $150 \mathrm{~mL}$ & 5,41 & 1,37 & 0,09 & 4,83 \\
Trichoderma $50 \mathrm{~mL}$ & 5,70 & 1,35 & 0,14 & 4,72 \\
Trichoderma $100 \mathrm{~mL}$ & 5,88 & 1,55 & 0,09 & 4,64 \\
Trichoderma $150 \mathrm{~mL}$ & 5,66 & 1,25 & 0,08 & 4,80 \\
Asam humat $5 \mathrm{~g}$ & & \\
Trichoderma $50 \mathrm{~mL}$ & 5,66 & 2,03 & 0,13 & 5,30 \\
Trichoderma $100 \mathrm{~mL}$ & 6,24 & 2,27 & 0,10 & 5,36 \\
Trichoderma $150 \mathrm{~mL}$ & 5,82 & 1,57 & 0,12 & 4,79 \\
\hline
\end{tabular}

Pertumbuhan dan perkembangan tanaman pakcoy dipengaruhi oleh faktor internal dan faktor eksternal. Faktor internal merupakan faktor yang terdapat pada benih atau tanaman itu sendiri. Faktor eksternal merupakan faktor yang terdapat di luar benih atau tanaman seperti media tanam. Media tanam yang baik adalah media yang mampu menyediakan air dan unsur hara dalam jumlah cukup bagi pertumbuhan tanaman (Fahmi, 2013). Media tanam yang digunakan pada penelitian ini adalah campuran dari kompos pelepah kelapa sawit, asam humat, 
dan Trichoderma sp. Pada Tabel 5 terlihat bahwa media tanam yang digunakan memiliki $\mathrm{pH}$ berkisar antara 5,31 - 6,24, C-organik 1,04-2,27 $\%$, N-total 0,08 - 0,14 \%. Menurut Balai Penelitian Tanah (2009), $\mathrm{pH}$ tanah tergolong masam-agak masam, C-organik dengan kategori rendah-sedang, dan $\mathrm{N}$-total dengan kategori sangat rendah-rendah.

$\mathrm{N}$ total pada media tanaman dengan perlakuan asam humat dosis 1, 3 dan $5 \mathrm{~g}$ memiliki rata-rata $0,11 \%, 0,10 \%$ dan $0,12 \%$. Kandungan $\mathrm{N}$ total media yang tertinggi adalah pada dosis asam humat $5 \%$. $\mathrm{N}$ total pada media tanam dengan perlakuan Trichoderma dengan dosis 50,100 , dan $150 \mathrm{~mL}$ yaitu $0,12 \%, 0,11 \%$ dan $0,10 \%$. Kaya et al. (2017) menunjukkan bahwa pemberian pupuk organik cair (POC) bersamasama dengan mikroorganisme terpilih (Trichoderma dan Azotobacter) meningkatkan $\mathrm{pH}$ di tanah ultisol. C-organik tanah menggambarkan kadar bahan organik secara keseluruhan yang ada dalam tanah. Benbi dan Ritcher (2002) menyatakan bahwa dalam proses dekomposisi, mikroorganisme memanfaatkan senyawa karbon dalam bahan organik untuk memperoleh energi dengan hasil sampingan berupa $\mathrm{CO}_{2}$. Hal ini yang menyebabkan selama dekomposisi, kadar $\mathrm{C}$ bahan organik akan berkurang sehingga nisbah $\mathrm{C} / \mathrm{N}$ semakin rendah.

Nitrogen merupakan unsur hara yang bersifat mobil dalam tanah sehingga mudah hilang karena tercuci. Menurut Damanik et al. (2010), nitrogen dibutuhkan selain untuk pertumbuhan tanaman juga untuk pembentukan sel-sel baru. Sarno dan Fitria (2012) melaporkan bahwa aplikasi asam humat melalui daun dapat meningkatkan pertumbuhan dan serapan $\mathrm{N}$ tanaman bayam secara kuadratik. Pada tabel juga terlihat nilai $\mathrm{N}$ total tanaman berkisar antara 4,59 - 5,36 \%. Kandungan N pada tanaman dengan perlakuan asam humat dosis 1 , 3 , dan 5 g memiliki rata-rata yaitu 4,73\%, 4,72\%, dan $5,33 \%$. Kandungan $N$ pada tanaman pakcoy dengan dosis asam humat $5 \mathrm{~g}$ lebih tinggi seiring dengan ketersediaan $\mathrm{N}$ total media tanam.

Perlakuan Trichoderma sp. sebanyak 50, 100, dan $150 \mathrm{~mL}$ mengandung $\mathrm{N}$ total tanaman masing-masing sebesar $4,93 \%, 4,88 \%$ dan $4,82 \%$. Berdasarkan hasil tersebut maka dosis Trichoderma sp. $50 \mathrm{~mL}$ dapat meningkatkan pertumbuhan pakcoy karena kandungan $\mathrm{N}$ pada tanaman tinggi seiring dengan kandungan $\mathrm{N}$ total pada media tanam.

\section{Kesimpulan}

Berdasarkan hasil penelitian maka dapat disimpulkan bahwa:

1. Aplikasi asam humat dan Trichoderma sp. memiliki pengaruh mandiri dan tidak terdapat interaksi.

2. Dosis Asam humat $3 \mathrm{~g}$ per tanaman memiliki jumlah daun, panjang daun, tinggi tanaman, bobot basah, dan bobot kering tanaman lebih tinggi dibanding dosis 1 dan $5 \mathrm{~g}$.

3. Perlakuan Trichoderma sp. dosis $50 \mathrm{~mL}$ per tanaman memiliki pengaruh lebih baik terhadap jumlah daun, panjang daun, tinggi tanaman, dan bobot basah tanaman.

\section{Ucapan Terima Kasih}

Penulis mengucapkan terima kasih kepada Kemendikbud Dikti yang telah memberikan dana penelitian melalui hibah Penelitian Dosen Pemula (PDP).

\section{Daftar Pustaka}

Benbi, D.K. and J. Richter. 2002. A critical review of some approaches to modelling nitrogen mineralization. Biol Fertil Soils. 35:168183.

Badan Pusat statistik \& Direktorat Jenderal Hortikultura. 2020. Produksi dan Impor Sayuran Di Indonesia.

Balai Penelitian Tanah. 2009. Analisis kimia tanah, tanaman, air, dan pupuk. Balai Penelitian Tanah. Bogor.

Bangun, R.A. 2016. Pengaruh Pupuk NPK dan Asam Humat Terhadap pH, C-Organik, N-total, C/N, KTK dan Hasil Pakcoy (Brassica chinensis, L) pada Inceptisols Jatinangor.

Damanik, M. M. B., B. E. Hasibuan, Fauzi, Sarifuddin, H. Hanum. 2010. Kesuburan Tanah dan Pemupukkan. Universitas Sumatera Utara. Medan.

Darmosarkoro, W. 2012. Integrasi Sawit Sapi dan Energi. Pusat penelitian Kelapa Sawit. Medan.

Fahmi, Z.I. 2013. Media Tanam Sebagai Faktor 
Eksternal yang Mempengaruhi Pertumbuhan Tanaman. Balai Besar Perbenihan dan Proteksi Tanaman Perkebunan. Surabaya.

Fauziah, I., E. Proklamasiningsih, dan I. Budisantoso. 2019. Pengaruh Asam Humat pada Media Tanam Zeolit terhadap Pertumbuhan dan Kandungan Vitamin C Sawi Hijau ( Brassica juncea). Bio Eksakta: Jurnal Ilmiah Biologi Unsoed, 1 (2): 17-21.

Herlina, L. dan D. Pramesti. 2009. Penggunaan Kompos Aktif Aktif Trichoderma sp. dalam Meningkatkan Pertumbuhan Tanaman Cabai. Fakultas Matematika Dan Ilmu Pengetahuan Alam Universitas Negeri Semarang. Semarang.

Kaya, E., C. H. Silahooy, Y. Risambessy. 2017. Pengaruh pemberian pupuk organic cair dan mikroorganisme terhadap keasaman dan P-tersedia pada tanah ultisol. J. Mikologi Indonesia. 1(2): 91-99.

Khaled, H. and H.A. Fawy. 2011. Effect of different levels of humic acids on the nutrient content, plant growth, and soil properties under conditions of salinity. Soil \& Water Res. 6(1): 21-29.

Malcolm, R. E. and D. Vaughan. 1979. Humic substances and phosphatase activities in plant tissues. Soil Biol. Biochem. 11: 253259.

Pettit. R. E. 2018. Organic Matter, Humus, Humate, Humic Acid, Fulvic acid and Humin: Their Importance in Soil Fertility and Plant Health. https://humates.com/pdf/ORGANIC.

Poulton, J. L., R. T. Koide, and A. G. Stephenson. 2011. Effects of Trichoderma infection and soil phosphorus availability on in-vitro and in-vivo pollen performance in Lycopersicon esculentum (Solanaceae). American J.Botany. 88: 1786-1793.

Priambodo, S.R., K.D. Susila, and N. N. Soniari. 2019. Pengaruh pupuk hayati dan pupuk anorganik terhadap beberapa sifat kimia tanah serta hasil tanaman bayam cabut (amaranthus tricolor) di tanah inceptisols Desa Pedungan. E-jurnal Agroteknologi Tropika. 8(1): 149-160.

Radite, S. dan B. H. Simanjuntak. 2020. Penggunaan Asam Humat Sebagai Pelapis Urea Terhadap Pertumbuhan dan hasil tanaman pakcoy ( Brassica rapa L .). Agriland. 8(1): 72-78.
Rizal, S., D. Novianti, dan M. Septiani. 2019. Pengaruh Jamur Trichoderma sp Terhadap Pertumbuhan Tanaman Tomat (Solanum lycopersicum L.). J.Indobiosains. 1(1): 1421.

Sakiah, S., M. Y. Dibisono, dan S. Susanti. 2019. Uji Kadar Hara Nitrogen, Fosfor, dan Kalium pada Kompos Pelepah Kelapa Sawit dengan Pemberian Trichoderma harzianum dan Kotoran Sapi. J.Agro Industri Perkebunan. 7(2): 87-95.

Saragih, J. S. 2015. Pengaruh asam humat dan pupuk NPK terhadap $\mathrm{pH} \mathrm{H} 2 \mathrm{O}, \mathrm{N}$-Total, Serapan N, dan hasil pakcoy (Brassica chinensis L.) pada inceptiols Jatinangor. Fakultas Pertanian Universitas Padjajaran. Jatinangor.

Sarno dan E. Fitria. 2012. Pengaruh aplikasi asam humat dan pupuk $\mathrm{N}$ terhadap pertumbuhan dan serapan $\mathrm{N}$ pada tanaman bayam (Amaranthus spp.). Prosiding SNSMAIP III-2012. (978): 288293.

Sembiring, J. V., N. Nelvia, dan A. E. Yulia. 2016. Pertumbuhan bibit kelapa sawit (Elaeis guineensis Jacq.) di pembibitan utama pada medium sub soil ultisol yang diberi asam humat dan kompos tandan kosong kelapa sawit. J.Agroteknologi. 6(1): 25.

Siregar, R. S., C. Zulia, dan Safruddin. 2018. Pengaruh pemberian dosis Trichoderma sp. dan jenis pupuk kandang terhadap pertumbuhan dan produksi tanaman kacang panjang (Vigna sinensis, L). Bernas Agricultural research journal. 14(2):21-34.

Sukri, M.Z., R. Firgiyanto, V. K. Sari, Basuki. 2019. Kombinasi pupuk kandang sapi, asam humat dan mikoriza terhadap infeksi akar bermikoriza tanaman cabai dan ketersediaan unsur hara tanah udipsamments. J. Penelitian Pertanian Terapan. 19(2): 141-145.

Suwardi dan H. Wijaya. 2013. Peningkatan produksi tanaman pangan dengan bahan aktif asam humat dengan zeolit sebagai pembawa. J.Ilmu Pertanian Indonesia. 18(2): 79-84.

Syahfitri, M. M. 2008. Analisa unsur hara fosfor (P) pada daun kelapa sawit secara spektrofotometri di Pusat Penelitian Kelapa Sawit (PPKS) Medan. Universitas Sumatera Utara. Medan.

Victolika, H., Sarno, dan Y. C. Ginting. 2014. Pengaruh pemberian asam humat dan $\mathrm{K}$ 
terhadap pertumbuhan dan produksi tanaman tomat (Lycopersicum Esculentum Mill). J. Agrotek Tropika. 2(2): 297-301.

Wahyuni, D. S. 2018. Pengaruh Dosis Asam Humat terhadap Pertumbuhan Bibit Tembakau (Nicotiana Tabacum L.) Menggunakan Benih Pillen/Seed Coating. Universitas Negeri Jember. Jember.

Yudha, M. K., L. Soesanto, dan E. Mugiastuti. 2016. Pemanfaatan empat isolat Trichoderma sp. untuk mengendalikan penyakit akar gada pada tanaman caisin.
J. Kultivasi. 15 (3): 143-149.

Yuniarti, A., M. Damayani, dan D. M. Nur. 2019. Efek pupuk organik dan pupuk NPK terhadap C-organik, N-total, C/N, serapan $\mathrm{N}$ serta hasil padi hitam pada inceptisols. J.Pertanian Presisi. 3(2): 90105.

Zainudin dan R. Kesumaningwati. 2020. Peranan kompos pelepah kelapa sawit dengan bioaktivator MOL POME terhadap peningkatan sifat biologi tanah sub optimal. Ziraa'ah. 45(3): 360-369. 